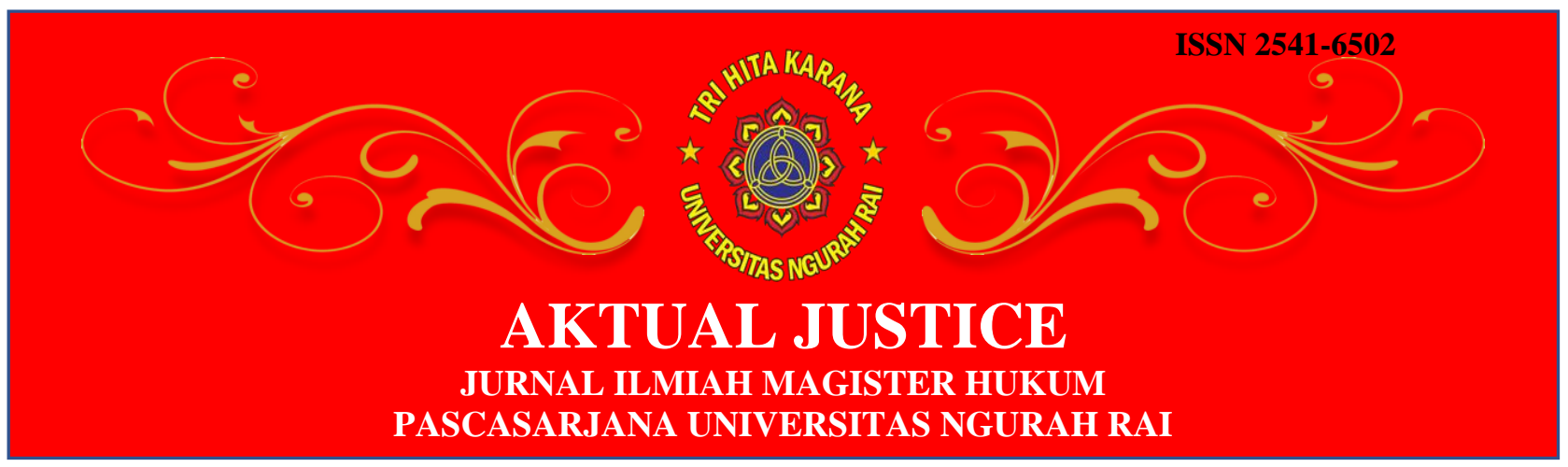

\title{
PENEGAKAN HUKUMAN DISIPLIN BERAT BAGI PEGAWAI NEGERI SIPIL (PNS) DALAM PERSPEKTIF HUKUM KEPEGAWAIAN
}

\author{
Adrie \\ Dosen Fakultas Hukum Universitas Ngurah Rai, Email : adsadho@gmail.com
}

\begin{abstract}
Civil Servants (PNS) are prohibited from providing support to candidates for President and Vice President by engaging in campaign activities because this is a violation and can be severely disciplined. The purpose of writing this scientific paper is to determine the effectiveness of severe disciplinary penalties according to employment law, and to know the process of severe disciplinary penalties for Civil Servants (PNS).

The author uses normative legal research methods with data collection techniques with literature study of legal materials through internet media. The data obtained in this legal research were analyzed using qualitative methods which were presented descriptively which would later obtain meanings and conclusions to answer the problem.

The conclusions from the writing of this scientific work are: (1) The absence of effectiveness of severe disciplinary penalties according to the employment law which now applies to Civil Servants (PNS) because in reality, lawlessness continues to occur among Civil Servants (PNS) even though it has been given severe disciplinary punishment so that there must be firmer law enforcement that should be regulated in the employment law; (2) The process of severe disciplinary punishment for Civil Servants (PNS), among others: (a). Civil servants who commit disciplinary violations are examined by the Examining Team consisting of elements of supervision, staffing and direct superiors; (b). LHP is reported in a hierarchical way to officials who have the authority to punish; (c). Preparation and Issuance of Decree for the Dismissal of PNS Discipline by Officials who have the authority to punish; (d). After the issuance of the Decree, then the PNS Discipline $S K$ is handed over to the concerned / Family / through electronic media (Postmark).

Keywords: Civil Servants, disciplinary violations, severe disciplinary penalties and law enforcement
\end{abstract}

\section{Abstrak}

Pegawai Negeri Sipil (PNS) dilarang memberikan dukungan kepada calon Presiden dan Wakil Presiden dengan cara terlibat dalam kegiatan kampanye karena hal ini termasuk pelanggaran dan dapat dijatuhi hukuman disiplin berat. Tujuan dari penulisan karya ilmiah ini adalah untuk mengetahui efektivitas hukuman disiplin berat menurut hukum kepegawaian, dan untuk mengetahui proses hukuman disiplin berat bagi Pegawai Negeri Sipil (PNS).

Penulis menggunakan metode penelitian hukum normatif dengan teknik pengumpulan data dengan studi pustaka terhadap bahan-bahan hukum melalui media internet. Data yang diperoleh 
dalam penelitian hukum ini dianalisis dengan menggunakan metode kualitatif yang dipaparkan secara deskriptif yang nantinya akan diperoleh arti dan kesimpulan untuk menjawab permasalahan.

Adapun kesimpulan dari penulisan karya ilmiah ini adalah: (1) Belum adanya efektivitas hukuman disiplin berat menurut hukum kepegawaian yang sekarang berlaku bagi Pegawai Negeri Sipil (PNS) karena pada kenyataannya, pelanggaran hukum terus terjadi di kalangan Pegawai Negeri Sipil (PNS) kendati sudah diberikan hukuman disiplin berat sehingga harus ada penegakan hukum yang lebih tegas yang seharusnya diatur dalam hukum kepegawaian; (2) Proses hukuman disiplin berat bagi Pegawai Negeri Sipil (PNS) antara lain: (a). PNS yang melakukan pelanggaran disiplin dilakukan pemeriksaan oleh Tim Pemeriksa yang terdiri dari unsur pengawasan, kepegawaian dan Atasan langsung; (b). LHP dilaporkan secara hierarki Kepada Pejabat yang berwenang menghukum; (c). Pembuatan dan Penerbitan SK Penjatuhan Hukuman Disiplin PNS oleh Pejabat yang berwenang menghukum; (d). Setelah SK Terbit kemudian selanjutnya dilakukan penyerahan SK Disiplin PNS terhadap yang bersangkutan/Keluarga/melalui media elektronik (Cap Pos).

Kata Kunci: Pegawai Negeri Sipil, pelanggaran disiplin, hukuman disiplin berat dan penegakan hukum

\section{Pendahuluan}

Pegawai Negeri Sipil (PNS) sebagai alat pemerintah (aparatur pemerintah) memiliki keberadaan yang sentral dalam membawa komponen kebijaksanaan-kebijaksanaan atau Peraturan-Peraturan Pemerintah guna terealisasinya tujuan nasional. Pegawai Negeri Sipil dinyatakan melanggar Peraturan Disiplin apabila dengan ucapan, tulisan, dan atau perbuatannya tersebut secara sah terbukti melanggar ketentuan mengenai kewajiban dan atau larangan Peraturan Pemerintah Nomor 53 Tahun 2010. ${ }^{1}$ Menurut Pasal 1 poin 3 Peraturan Pemerintah Nomor 53 tahun 2010 tentang Disiplin PNS disebutkan bahwa yang dinamakan pelanggaran disiplin adalah setiap ucapan, tulisan, atau perbuatan PNS yang tidak menaati kewajiban dan/atau melanggar larangan ketentuan disiplin PNS, baik yang dilakukan di dalam maupun di luar jam kerja.

Pada siaran pers Kepala Biro Hubungan Masyarakat (Humas) BKN yang dilakukan pada tanggal 8 Februari 2019 lalu, beliau dengan tegas

1 Yusuf, A. (2015). Pemberian Sanksi Pelanggaran Disiplin Aparatur Sipil Negara Dilingkungan Pemerintah Daerah Kabupaten Sigi Guna Meningkatkan Pelayanan Publik, e-Jurnal Katalogis, Volume 3 Nomor 11, Nopember 2015 hlm 118-129, h. 119 
menekankan bahwa Pegawai Negeri Sipil (PNS) dilarang memberikan dukungan kepada calon Presiden dan Wakil Presiden dengan cara: Terlibat dalam kegiatan kampanye untuk mendukung calon Presiden dan Wakil Presiden; Menggunakan fasilitas yang terkait dengan jabatan dalam kegiatan kampanye; Membuat keputusan dan atau tindakan yang menguntungkan atau merugikan salah satu pasangan calon selama masa kampanye; dan/atau Mengadakan kegiatan yang mengarah kepada keberpihakan terhadap pasangan calon yang menjadi peserta Pemilu sebelum, selama dan sesudah masa kampanye meliputi pertemuan, ajakan, imbauan, seruan atau pemberian barang/uang kepada PNS dalam lingkungan kerjanya, anggota keluarga dan masyarakat dimana kegiatankegiatan tersebut dapat dilakukan secara langsung maupun tidak langsung termasuk dengan menggunakan media sosial seperti Twitter, Facebook, WhatsApp, BBM, Line, SMS, lnstagram, Blog, dan sejenisnya.

Meskipun Kepala Badan Kepegawaian Negara (BKN) sudah mengingatkan seluruh Pegawai Negeri Sipil (PNS) untuk menjaga netralitas dan tetap berkomitmen menempatkan peran dan fungsinya secara proporsional, sehubungan dengan adanya Pemilihan Umum Presiden, Wakil Presiden (Pilpres) dan Anggota Legislatif (Pileg) pada bulan April 2019 lalu, namun masih banyak kasus pelanggaran disiplin Pegawai Negeri Sipil (PNS).

Dilansir dari situs Badan Kepegawaian Negara (BKN), beberapa waktu lalu tepatnya pada tanggal 14 Oktober 2019 di Kantor Pusat BKN Jakarta telah dilakukan prasidang guna mengupas 35 kasus pelanggaran disiplin Pegawai Negeri Sipil (PNS) yang berstatus pegawai instansi pusat dan daerah. Pasal 7 Peraturan Pemerintah Nomor 53 tahun 2010 tentang Disiplin PNS, yang meliputi hukuman disiplin ringan berupa teguran lisan atau tulisan, hukuman disiplin sedang berupa penurunan pangkat, dan hukuman disiplin berat berupa pemberhentian. Prasidang ini 
dipimpin oleh Kepala BKN selaku Sekretariat Badan Pertimbangan Kepegawaian (Bapek) bersama Tim dan masing-masing perwakilan dari Kementerian Pendayagunaan Aparatur dan Reformasi Birokrasi, Sekretariat Kabinet, Kejaksaan Agung, Ditjen Per-UU Kementerian Hukum dan HAM, serta Dewan Pengurus Nasional Korpri. Dari uraian singkat latar belakang diatas, penulis ingin membahas lebih lanjut dalam tulisan karya ilmiah dengan judul Penegakan Hukuman Disiplin Berat Bagi Pegawai Negeri Sipil (PNS) Dalam Perspektif Hukum Kepegawaian.

\section{Metode Penelitian}

Metodologi adalah suatu sarana pokok pengembangan ilmu pengetahuan dan teknologi, oleh karena itu suatu penelitian bertujuan untuk mengungkapkan kebenaran secara sistematis, metodologis dan konsisten dengan mengadakan analisa dan konstruksi. ${ }^{2}$ Penelitian hukum merupakan kegiatan ilmiah, yang didasarkan pada metode, sistematika dan pemikiran tertentu, yang bertujuan untuk mempelajari satu atau beberapa gejala hukum tertentu, dengan jalan menganalisanya. ${ }^{3}$ Penulis menggunakan metode penelitian hukum normatif atau metode penelitian hukum kepustakaan yaitu metode atau cara yang dipergunakan di dalam penelitian hukum yang dilakukan dengan cara meneliti bahan pustaka yang ada. ${ }^{4}$ Suatu penelitian normatif tentu harus menggunakan pendekatan perundang-undangan, karena yang akan diteliti adalah berbagai aturan hukum yang menjadi fokus sekaligus tema sentral suatu penelitian. ${ }^{5}$

${ }^{2}$ Soekanto, S dan Mamudji, S. (1990). Penelitian Hukum Normatif Suatu Tinjauan Singkat. Cet. 3. Jakarta: Rajawali Pers. h. 1.

3Soekanto, S. (2006). Pengantar Penelitian Hukum. Jakarta: Penerbit Universitas Indonesia. h. 43.

4 Soekanto, S dan Mamudji, S. (2009). Penelitian Hukum Normatif Suatu Tinjauan Singkat, Cetakan ke - 11. Jakarta: PT Raja Grafindo Persada, h. 13-14.

${ }^{5}$ Marzuki, P.M. (2008). Penelitian Hukum. Cet 2. Jakarta: Kencana, h. 29 
Adapun jenis dan sumber data yang akan digunakan sebagai dasar untuk menunjang penelitian ini adalah data yang dikumpulkan berasal dari data sekunder. Data sekunder dimaksud antara lain meliputi bahan hukum primer, bahan hukum sekunder dan bahan hukum tertier berupa norma dasar, perundang-undangan, hasil penelitian ilmiah, buku-buku dan lain sebagainya. 6 Bahan hukum primer yaitu bahan hukum yang mempunyai kekuatan mengikat sebagai landasan utama yang dipakai dalam rangka penelitian ini, sedangkan bahan hukum sekunder yaitu bahan-bahan yang erat hubungannya dengan bahan hukum primer dan dapat membantu menganalisis dan memahami bahan hukum primer, seperti hasil-hasil penelitian, hasil seminar, hasil karya dari kalangan hukum, serta dokumen-dokumen lain. ${ }^{7}$

Dalam penelitian hukum normatif atau kepustakaan teknik pengumpulan data dalam penelitian hukum normatif dilakukan dengan studi pustaka terhadap bahan-bahan hukum, baik bahan hukum primer, bahan hukum sekunder, maupun bahan hukum tersier dan atau bahan nonhukum. Penelusuran bahan hukum tersebut dengan melalui media internet. ${ }^{8}$ Data yang diperoleh dalam penelitian hukum ini dianalisis dengan menggunakan metode kualitatif, yaitu metode analisis data dengan cara mengelompokkan dan menseleksi data yang diperoleh dari penelitian lapangan menurut kualitas dan kebenarannya kemudian disusun secara sistematis, yang selanjutnya dikaji dengan metode berfikir secara deduktif dihubungkan dengan teori-teori dari studi kepustakaan (data sekunder), kemudian dibuat kesimpulan yang

${ }^{6}$ Amiruddin, Asikin, Z. (2004). Pengantar Metode Penelitian Hukum. Jakarta: Raja Grafindo Persada, h. 30

7 Soemitro, R.H. (1990). Metodologi Penelitian Hukum dan Jurimetri. Jakarta: Ghalia Indonesia, h. 53

8 Fajar, M dan Achmad, Y. (2010). Dualisme Penelitian Hukum Normatif dan Empiris, Yogyakarta: Pustaka Pelajar, h. 160 
berguna untuk menjawab rumusan masalah dalam penelitian ini. Hasil analisis tersebut dipaparkan secara deskriptif, yaitu cara menggambarkan keadaan sebenarnya di lapangan sehingga diperoleh uraian hasil penelitian yang bersifat deskriptif-kualitatif yang nantinya akan diperoleh arti dan kesimpulan untuk menjawab permasalahan. ${ }^{9}$

\section{Hasil Dan Pembahasan}

\section{a. Penegakan Hukum}

Penegakan dalam Kamus Besar Bahasa Indonesia berasal dari kata dasar "tegak" yang artinya: a. berdiri; b. sigap; c. lurus arah ke atas; d. setinggi orang berdiri; e. tetap teguh; tetap tidak berubah. Untuk bisa memahami penegakan hukum maka diharuskan memahami unsur-unsur prinsipnya. Dalam hal ini, penegakan hukum yang baik telah mengacu kepada prinsip demokrasi, legitimasi, akuntabilitas, perlindungan hak asasi manusia, kebebasan, transparansi, pembagian kekuasaan dan control masyarakat. Penegakan hukum diartikan dalam 3 konsep, sebagai berikut: (1) Konsep penegakan hukum bersifat total (total enforcement concept) yaitu menuntut untuk semua nilai yang ada di belakang norma hukum agar ditegakkan tanpa terkecuali; (2) Konsep penegakan hukum yang bersifat penuh (full enforcement concept), yaitu konsep total harus dibatasi dengan hukum acara dan demi melindungi kepentingan individual; (3) Konsep penegakan hukum aktual (actual enforcement concept) yaitu yakin bahwa ada diskresi dalam penegakan hukum karena keterbatasan yang berkaitan dengan sarana prasarana, kualitas sumber daya manusia, kualitas perundang-undangan dan kurangnya peran masyarakat. ${ }^{10}$

${ }^{9}$ Muhammad, A. (2004). Hukum dan Penelitian Hukum. Cet. 1. Bandung: PT. Citra AdityaBakti. h. 50-51

10 Sunarso, S. (2012). Victimologi Dalam Sistem Peradilan Pidana. Jakarta Timur: Sinar Grafika, h. 88. 
Dengan demikian penegakan hukum adalah suatu usaha untuk menanggulangi kejahatan secara rasional, memenuhi rasa keadilan dan berdaya guna. Dalam rangka menanggulangi kejahatan terhadap berbagai sarana sebagai reaksi yang dapat diberikan kepada pelaku kejahatan, berupa sarana pidana maupun non hukum pidana, yang dapat diintegrasikan satu dengan yang lainnya. ${ }^{11}$ Penegakan hukum mengandung makna bahwa tindak pidana adalah suatu perbuatan yang dilarang oleh suatu aturan hukum, di mana larangan tersebut disertai dengan ancaman (sanksi) yang berupa pidana tertentu sebagai pertanggungjawabannya. Pelaku dapat dikenai sanksi atau hukuman, sedangkan ancaman pidananya ditujukan kepada orang yang menimbulkan kejadian itu. ${ }^{12}$ Pokok dan maksud dari penegakan hukum dengan adanya aktivitas menyesuaikan hubungan nilai yang terdapat pada kaidah-kaidah yang kukuh dan mengejewantah disertai dengan tindakan selaku rangkaian pemaparan nilai proses terakhir, demi mewujudkan, menjaga dan mempertahankan ketentraman pergaulan hidup. ${ }^{13}$

\section{b. Hukum Kepegawaian}

Hukum Kepegawaian ialah hukum yang mengatur dan menjelaskan tentang kedudukan Pegawai Negeri yang dipelajari di dalam Hukum Administrasi Negara, yang menyebutkan bahwa Pegawai Negeri mempunyai suatu hubungan dinas publik. Hubungan dinas publik adalah bilamana seseorang mengikatkan dirinya sendiri, untuk tunduk pada perintah melakukan satu atau beberapa macam jabatan, yang dalam

${ }^{11}$ Arief, B.N. (2002). Kebijakan Hukum Pidana. Bandung: PT. Citra Aditya Bakti. h. 109

12 Hamzah, A. (2001). Asas-Asas Hukum Pidana. Jakarta: Rineka Cipta. h. 15

${ }^{13}$ Soekanto, S. (2016). Faktor-Faktor Yang Mempengaruhi Penegakan Hukum. Jakarta: PT. Raja Grasindo Persada. h. 5. 
melakukan suatu atau beberapa macam jabatan itu dihargai dengan pemberian gaji dan beberapa keuntungan lain. ${ }^{14}$

Menurut Kamus Besar Bahasa Indonesia, hukum merupakan: (1) peraturan atau adat, yang secara resmi dianggap mengikat dan dikukuhkan oleh penguasa, pemerintah atau otoritas; (2) Undangundang, peraturan dan sebagainya untuk mengatur kehidupan masyarakat; (3) Patokan (kaidah, ketentuan); (4) Keputusan (pertimbangan) yang ditentukan oleh hakim dalam pengadilan, vonis. Menurut Achmad Ali, hukum adalah norma yang mengatur mana yang benar dan mana yang salah, yang eksistensi atau pembuatannya dilakukan oleh pemerintah, baik itu secara tertulis ataupun tidak tertulis, dan memiliki ancaman hukuman bila terjadi pelanggaran terhadap norma tersebut, sedangkan menurut Utrecht, hukum adalah himpunan petunjuk hidup (perintah dan larangan) yang mengatur tata tertib dalam suatu masyarakat yang seharusnya ditaati oleh anggota masyarakat dan jika dilanggar dapat menimbulkan tindakan dari pemerintah. ${ }^{15}$

Kepegawaian berasal dari kata dasar pegawai. Kepegawaian memiliki arti dalam kelas nomina atau kata benda sehingga kepegawaian dapat menyatakan nama dari seseorang, tempat, atau semua benda dan segala yang dibendakan. Dengan demikian kepegawaian adalah segala sesuatu yang berhubungan dengan pegawai16, sedangkan menurut Kamus Umum Bahasa Indonesia “Pegawai” berarti “orang yang bekerja pada pemerintahan (perusahaan dan sebagainya)" .17 Dari uraian diatas, dapat disimpulkan bahwa yang dinamakan hukum kepegawaian adalah

14 Djatmika, S dan Marsono. (1995). Hukum Kepegawaian di Indonesia. Jakarta: Djambatan, h. 17

15 https:/ / www.eduspensa.id/hukum/ diakses tanggal 10 Nopember 2019

16 https:/ / lektur.id/arti-kepegawaian/ diakses tanggal 10 Nopember 2019

17 Hartini, S, Sudrajat, T, Kadarsih, S. (2008). Hukum Kepegawaian Di Indonesia. Jakarta: Sinar Grafika, h. 31. 
Undang-undang atau peraturan yang berhubungan dengan orang yang bekerja pada pemerintahan (perusahaan dan sebagainya).

\section{c. Hukuman Disiplin}

Menurut Pasal 1 poin 4 Peraturan Pemerintah Nomor 53 tahun 2010 tentang Disiplin PNS menyebutkan bahwa yang dinamakan hukuman disiplin adalah hukuman yang dijatuhkan kepada PNS karena melanggar peraturan disiplin PNS, sedangkan ketentuan dalam Pasal 7 Peraturan Pemerintah Nomor 53 tahun 2010 tentang Disiplin PNS menyebutkan bahwa tingkat hukuman disiplin terdiri dari: (a). hukuman disiplin ringan; (b). hukuman disiplin sedang; dan (c). hukuman disiplin berat.

\section{STUDI KASUS}

\section{Data}

Pelanggaran netralitas PNS sebagian besar dilakukan melalui medsos, mulai dari menyebarluaskan gambar pasangan calon, memberikan dukungan, berkomentar, sampai mengunggah foto untuk menyatakan keberpihakan terhadap pasangan calon (paslon) tertentu. Selain aktivitas medsos, pelanggaran netralitas yang diterima juga berupa bentuk dukungan secara langsung misalnya menghadiri kampanye paslon dan kegiatan yang bersinggungan dengan partai politik paslon. ${ }^{18}$

Sesuai ketentuan Undang-Undang (UU) 5/2014 tentang Aparatur Sipil Negara (ASN), disebutkan bahwa abdi negara harus menjalankan fungsinya tanpa intervensi politik, sesuai pasal 12 UU ASN. Badan Kepegawaian Negara (BKN) menemukan aktivitas politik aparatur sipil negara (ASN) seperti keberpihakan terhadap calon pasangan tertentu dalam Pilkada 2018 dan 2019 dan Pemilu 2019. Berdasarkan data BKN, sebanyak 991 ASN terlibat dalam pelanggaran netralitas. Ini merupakan data per Januari 2018 sampai dengan Juni 2019. Jenis pelanggaran

18https:// www.liputan6.com/bisnis/read/3939766/bkn-temukan-990-pelanggarannetralitas-pns diakses tanggal 10 Nopember 2019 
netralitas yang berkategori hukuman disiplin berat. Sanksi yang akan diterapkan penurunan pangkat setingkat lebih rendah selama tiga tahun, dan penurunan jabatan setingkat lebih rendah serta pembebasan jabatan, hingga pemberhentian dengan hormat tidak atas permintaan sendiri sebagai PNS. ${ }^{19}$ Komisi Aparatur Sipil Negara (KASN) menerima sekitar 200 laporan soal keterlibatan pegawai negeri sipil dalam kampanye pemilihan kepala daerah atau Pilkada 2018. Beberapa di antaranya dihukum berat dengan dipecat dari pekerjaannya. ${ }^{20}$

\section{Studi Kasus}

Persoalan netralitas ASN masih mengemuka, terutama di Kabupaten Bima, Kabupaten Sekadau dan Kabupaten Mamasa. Persoalan tersebut menjadi kasat mata ketika ASN ikut berpartisipasi dan terkesan mendukung salah satu paslon tertentu. Kondisi tersebut tentu saja menjadi pelajaran buruk bagi masyarakat yang terus mengedepankan slogan jujur dan berkeadilan dalam berdemokrasi. Ketidaknetralan ASN justru akan menimbulkan kekisruhan internal, sehingga BKD bersama Panwaslu dapat terus memonitor secara ketat. Keterlibatan ASN dalam berpolitik praktis memang cukup rawan terjadi mengingat hal tersebut akan berpengaruh pada jabatan ASN yang mendukung terhadap calon tertentu, apalagi calon yang didukungnya mampu memenangkan Pilkada. Selama ini, kendala dalam menangani permasalahan keterlibatan ASN terkait dengan pembuktian sesuai dengan aturan yang ada, sehingga kasus tersebut akan terhambat dan terhenti akibat kurangnya bukti-bukti untuk mendukung penanganan kasus keterlibatan ASN dalam politik

\footnotetext{
${ }^{19}$ https://www.cnbcindonesia.com/news/20190726075238-4-87722/pns-ingatdilarang-dukung-capres diakses tanggal 10 Nopember 2019

20https:// www.kasn.go.id/details/item/235-pilkada-2018-kasn-terima-200-laporanpns-terlibat-kampanye diakses tanggal 10 Nopember 2019
} 
praktis. ${ }^{21}$ Berdasarkan hasil pemeriksaan, dari delapan ASN, ada enam yang diikutsertakan langsung oleh salah seorang Caleg. Sementara dua sisanya terlibat aktif mengkampanyekan Caleg. Mereka ada yang sengaja menghadiri undangan pertemuan dan juga sebagai pembawa acara Caleg saat bertemu dengan masyarakat. ${ }^{22}$

Berdasarkan hasil kajian bidang Pengkajian dan Pengembangan Sistem Komisi Aparatur Sipil Negara (KASN), bentuk pelanggaran netralitas ASN sering terjadi dalam pemilihan kepala daerah dan/atau pemilihan umum. Misalnya seorang petahana yang maju dalam kontestasi pemilihan kepala daerah, melalui ASN yang berada di lingkungan kerjanya secara sengaja membuat kegiatan yang bersumber dari anggaran negara/daerah untuk kepentingan pejabat petahana seperti sosialisasi dan/atau bagi sembako dalam rangka menarik simpati rakyat yang menguntungkan pihak petahana. Contoh lainnya, kampanye terselubung dengan sengaja memasang baliho atau banner yang digunakan untuk meningkatkan tingkat popularistas petahana dengan menggunakan anggaran negara atau daerah. ${ }^{23}$

Kasus yang pernah terjadi yaitu gara-gara foto dengan pose dua jari dan menunjukkan stiker Prabowo-Sandi, enam guru honorer di Tangerang dipecat. Kepala Badan Kepegawaian Daerah (BKD) Banten Komarudin mengatakan, keenam aparatur sipil negara (ASN) itu dianggap telah melanggar peraturan, salah satunya tidak boleh berkampanye di lingkungan pendidikan. Kepala Badan Kepegawaian Daerah (BKD) Banten Komarudin mengatakan, keenam guru tersebut dipecat satu hari setelah foto tersebut

${ }^{21}$ https:// baliexpress.jawapos.com/read/2018/05/28/77091/soal-masa-kampanyepilkada-2018-dan-masalah-netralitas-asnpns diakses tanggal 10 Nopember 2019

${ }^{22}$ https://www.suarantb.com/politik/2018/12/264987/Terlibat.Kampanye,Delapan .ASN.di.Bima.Langgar.Netralitas/ diakses tanggal 10 Nopember 2019

23Perdana, G. (2019). Menjaga Netralitas ASN dari Politisasi Birokrasi, Jurnal Negara Hukum: Vol. 10, No. 1, Juni 2019, h. 110-111 
viral di media sosial. Keenamnya juga disebut melanggar aturan lantaran menggunakan atribut, seperti seragam dan terdapat logo Provinsi Banten di bagian lengannya. Pemecatan enam guru tersebut sudah sesuai aturan yang berlaku. Salah satunya, tidak boleh berkampanye di lembaga pendidikan, termasuk sekolah. ${ }^{24}$

\section{Pembahasan}

\section{Efektivitas Hukuman Disiplin Berat Menurut Hukum Kepegawaian}

Perhelatan pilkada serentak 2018 menyeret berbagai kelompok masyarakat dalam pusaran politik praktis. Salah satu kelompok masyarakat yang ikut terseret adalah Pegawai Negeri Sipil (PNS) atau sekarang dikenal dengan Aparatur Sipil Negara (ASN). Mengingat jumlahnya yang cukup besar yaitu 4,3 juta jiwa dan posisinya yang strategis di tengah-tengah masyarakat, maka ASN merupakan kekuatan yang paling rentan dipolitisasi. Jargon "Netralitas ASN" pun lantang diteriakkan. ASN tidak boleh berpolitik praktis. Sebagai abdi negara dan abdi masyarakat, ASN harus netral dan tidak melakukan aksi dukungmendukung terhadap kontestan pilkada. Begitulah kira-kira harapan masyarakat agar birokrasi tetap profesional. ${ }^{25}$

Netralitas Aparatur Sipil Negara (ASN) bukanlah hal baru dalam kehidupan demokrasi di Indonesia. Dengan kata lain, persoalan netralitas ASN menjadi isu lama yang senantiasa aktual dalam kehidupan

${ }^{24}$ https://regional.kompas.com/read/2019/03/22/10045051/5-fakta-kasus-foto-6asn-acungkan-2-jari-di-sekolah-bawa-stiker-prabowo?page=all diakses tanggal 10 Nopember 2019

25https:/ / kumparan.com/birokrat-menulis/menumbuhkan-kesadaran-politikkritis-asn-zaman-now diakses tanggal 10 Nopember 2019 
bernegara terutama menjelang pelaksaan pesta demokrasi. ${ }^{26}$ Dalam UU Pemilu Tahun 2017, pengaturan tentang netralitas ASN diatur dalam Pasal 280 ayat (2) dan ayat (3) dimana ASN dilarang ikut serta dalam pelaksanaan dan kegiatan kampanye Pemilu. Apabila ASN tersebut tetap ikut kampanye, maka sebagaimana diatur dalam Pasal 494 akan dikenakan sanksi pidana dengan pidana kurungan paling lama 1 tahun dan denda paling banyak Rp12.000.000.27 Asas netralitas berdasarkan Undang-Undang Nomor 5 Tahun 2014 tentang Aparatur Sipil Negara (ASN)adalah bahwa setiap Pegawai ASN tidak berpihak dari segala bentuk pengaruh manapun dan tidak memihak kepada kepentingan siapapun.

Undang-Undang Nomor 5 Tahun 2014 tentang Aparatur Sipil Negara (ASN) memang tidak melarang pegawai negeri menggunakan suaranya pada pemilu. Mereka hanya diwajibkan menjaga netralitas dan tidak berpihak terhadap parpol atau kepentingan politik tertentu. ${ }^{28}$ Netralitas dapat juga diartikan dengan bersikap tidak memihak terhadap sesuatu apapun. Dalam konteks ini netralitas diartikan sebagai tidak terlibatnya pegawai negeri sipil dalam pemilihan Kepala Daerah baik secara aktif maupun pasif. ${ }^{29}$ Netralitas birokrasi pada hakikatnya adalah suatu sistem dimana birokrasi tidak akan berubah dalam memberikan pelayanan kepada masternya (dari parpol yang memerintah), biarpun masternya berganti dengan master (parpol) lain. Pemberian pelayanan tidak bergeser sedikit pun walau masternya berubah. Birokrasi dalam

${ }^{26}$ Nugraha, H.S. (2018). Politik Hukum Pengaturan Netralitas Aparatur Sipil Negara Dalam Pemilihan Kepala Daerah Tahun 2018. Jurnal Justisi Hukum. ISSN 2528-2638 Vol 3, No. 1, September 2018, h. 21

27 https://www.hukumonline.com/berita/baca/lt5c9336c8ba66d/pemilu-2019-dannetralitas-asn-oleh--hani-adhani/ diakses tanggal 10 Nopember 2019

${ }^{28}$ https://tirto.id/ bawaslu-izinkan-asn-ikut-kampanye-pilkada-dan-pemilu-cJMj diakses tanggal 10 Nopember 2019

29 Yamin, M. H. (2013). Netralitas Pegawai Negeri Sipil dalam Pemilihan Umum Kepala Daerah di Kabupaten Takalar. Makasar: Bagian Hukum Tata Negara Fakultas Hukum, h. 13 
memberikan pelayanan berdasarkan profesionalisme bukan karena kepentingan politik. ${ }^{30}$

Pegawai Negeri Sipil (PNS) merupakan pedoman sikap tingkah laku dan perbuatan di dalam dan di luar kedinasan. Untuk itu setiap PNS harus menaati peraturan perundang-undangan serta melaksanakan tugas jabatannya dengan penuh pengabdian dan tanggung jawab. Setiap pelanggaran terhadap kewajiban, kode etik dan kode perilaku akan berdampak kepada masa depan status kepegawaian seorang PNS sebagaimana yang diatur dalam peraturan perundang-undangan. ${ }^{31}$ Pelanggaran hukum adalah tindakan seseorang atau sekelompok yang melanggar aturan dan tidak sesuai dengan hukum-hukum yang berlaku. Pelanggaran hukum adalah bentuk pembangkangan terhadap hukum yang berlaku. Pelanggaran hukum itu bisa terjadi karena dua hal, yaitu pelanggaran yang oleh si pelanggar sudah dianggap sebagai kebiasaan bahkan kebutuhan. Hukum dibuat dengan tujuan untuk mengatur masyarakat, bukan untuk dilanggar oleh masyarakat. ${ }^{32}$

Sesuai dengan ketentuan dalam Pasal 7 ayat (4) Peraturan Pemerintah Nomor 53 tahun 2010 tentang Disiplin PNS disebutkan bahwa hukuman disiplin berat terdiri dari: (a). penurunan pangkat setingkat lebih rendah selama 3 (tiga) tahun; (b). pemindahan dalam rangka penurunan jabatan setingkat lebih rendah; (c). pembebasan dari jabatan; (d). pemberhentian dengan hormat tidak atas permintaan sendiri sebagai PNS; dan (e). pemberhentian tidak dengan hormat sebagai PNS.

${ }^{30}$ Patria, A. (2015). Intervensi Politik dan Netralitas Aparatur Sipil Negara dalam Pemilihan Umum Kepala Daerah Provinsi Lampung Tahun 2014. Bandar Lampung: Faklutas Ilmu Sosial dan Ilmu Politik Universitas Lampung, h. 21

${ }^{31}$ Muvariz, F.R. (2019). Analisis Aspek Keadilan Dari Pemberhentian Tidak Dengan Hormat Sebagai Pegawai Negeri Sipil Di Indonesia. Jurnal Legislasi Indonesia Vol 16 No.2 - Juni 2019: 190-202, h. 194

32https:/ / www.liputan6.com/citizen6/read/3871421/pengertian-hukum-adalahdan-jenis-jenisnya-yang-harus-dipelajari-biar-tak-salah-kaprah diakses tanggal 10 Nopember 2019 
Berdasarkan Peraturan Pemerintah Nomor 53 tahun 2010 tentang Disiplin PNS, hukuman disiplin berat tersebut dijatuhkan bagi pelanggaran terhadap larangan: (1) menyalahgunakan wewenang; (2) menjadi perantara untuk mendapatkan keuntungan pribadi dan/atau orang lain dengan menggunakan kewenangan orang lain; (3) tanpa izin Pemerintah menjadi pegawai atau bekerja untuk negara lain dan/atau lembaga atau organisasi internasional; (4) bekerja pada perusahaan asing, konsultan asing, atau lembaga swadaya masyarakat asing; (5) memiliki, menjual, membeli, menggadaikan, menyewakan, atau meminjamkan barang-barang baik bergerak atau tidak bergerak, dokumen atau surat berharga milik negara secara tidak sah; (6) melakukan kegiatan bersama dengan atasan, teman sejawat, bawahan, atau orang lain di dalam maupun di luar lingkungan kerjanya dengan tujuan untuk keuntungan pribadi, golongan, atau pihak lain, yang secara langsung atau tidak langsung merugikan Negara; (7) memberi atau menyanggupi akan memberi sesuatu kepada siapapun baik secara langsung atau tidak langsung dan dengan dalih apapun untuk diangkat dalam jabatan; (8) menerima hadiah atau suatu pemberian apa saja dari siapapun juga yang berhubungan dengan jabatan dan/atau pekerjaannya; (9) melakukan suatu tindakan atau tidak melakukan suatu tindakan yang dapat menghalangi atau mempersulit salah satu pihak yang dilayani sehingga mengakibatkan kerugian bagi yang dilayani; (10) menghalangi berjalannya tugas kedinasan; (11) memberikan dukungan kepada calon Presiden/Wakil Presiden, Dewan Perwakilan Rakyat, Dewan Perwakilan Daerah, atau Dewan Perwakilan Rakyat Daerah dengan cara sebagai peserta kampanye dengan menggunakan fasilitas negara; (12) memberikan dukungan kepada calon Presiden/Wakil Presiden dengan cara membuat keputusan dan/atau tindakan yang menguntungkan atau merugikan salah satu pasangan calon selama masa kampanye; (13) 
memberikan dukungan kepada calon Kepala Daerah/Wakil Kepala Daerah, dengan cara menggunakan fasilitas yang terkait dengan jabatan dalam kegiatan kampanye dan/atau membuat keputusan dan/atau tindakan yang menguntungkan atau merugikan salah satu pasangan calon selama masa kampanye.

Penegakan disiplin terhadap pegawai negeri sipil (PNS) dinilai masih belum bisa dilakukan secara maksimal. Kondisi ini salah satunya akibat Peraturan Pemerintah (PP) Nomor 53/2010 tentang Disiplin PNS belum secara tegas dan rinci mengatur disiplin PNS. Implementasi tentang aturan teknis tersebut pun masih jauh dari harapan. Apalagi, dalam pelaksanaannya sangat bergantung pada subjektivitas pejabat pembina kepegawaian (PPK). PP ini sebenarnya tidak gamblang mengatur tentang penegakan disiplin bagi PNS. Masih ada kelemahankelemahan sehingga penegakan disiplin PNS belum maksimal. PP tentang Disiplin PNS hanya berbicara tentang jenis sanksi yaitu ringan, sedang, dan berat. Sementara pelanggarannya didefinisikan oleh masing-masing PPK. Ada pelanggaran yang seharusnya mendapat sanksi berat, tapi hanya mendapat teguran. Misalnya tidak masuk berhari-hari tanpa kejelasan itu hanya mendapat sanksi teguran. Ada juga yang terkena narkoba lalu rehabilitasi, dan setelah itu kembali lagi bekerja. Kelonggaran-kelonggaran inilah yang dinilai membuat banyak PNS tidak begitu khawatir melakukan pelanggaran. Terlebih lagi, jika memiliki kedekatan dengan PPK, dipastikan lolos dari sanksi yang berat. ${ }^{33}$

Dengan demikian, dapat penulis simpulkan bahwa belum adanya efektivitas hukuman disiplin berat menurut hukum kepegawaian yang sekarang berlaku bagi Pegawai Negeri Sipil (PNS) karena pada kenyataannya, pelanggaran hukum terus terjadi di kalangan Pegawai

33https://nasional.sindonews.com/read/1281390/15/penegakan-disiplin-pnsdinilai-belum-maksimal-ini-penyebabnya-1518411884 diakses tanggal 10 Nopember 2019 
Negeri Sipil (PNS) kendati sudah diberikan hukuman disiplin berat sehingga harus ada penegakan hukum yang lebih tegas yang seharusnya diatur dalam hukum kepegawaian.

\section{Proses Hukuman Disiplin Berat Bagi Pegawai Negeri Sipil (PNS)}

Menurut Peraturan Pemerintah Nomor 53 tahun 2010 tentang Disiplin PNS Pasal 1 pada poin 1 menyebutkan bahwa Disiplin Pegawai Negeri Sipil (PNS) adalah kesanggupan Pegawai Negeri Sipil untuk menaati kewajiban dan menghindari larangan yang ditentukan dalam peraturan perundang-undangan dan/atau peraturan kedinasan yang apabila tidak ditaati atau dilanggar dijatuhi hukuman disiplin.

Kadang kala ASN mudah terbawa arus politik atau dengan kata lain dalam keadaan terpaksa untuk memihak kepada salah satu pasangan calon ketika salah satu kandidat merupakan calon pertahana (incumbent). Ketidaknetralan ASN juga sangat terlihat ketika ada calon kepala daerah berasal dari keluarganya sehingga nilai-nilai seharusnya dimiliki terbuang dan ditinggalkan. Tidak mengherankan jika banyak proses politik dalam Pilkada dicederai karena adanya keterlibatan ASN secara langsung dalam mendukung salah satu paslon kepala daerah. ${ }^{34}$ Badan Kepegawaian Negara (BKN) selaku instansi yang bertugas mengawasi dan mengendalikan pelaksanaan norma, standar, dan prosedur manajemen kepegawaian ASN (sesuai dengan ketentuan dalam UndangUndang Nomor 5 Tahun 2014 tentang Aparatur Sipil Negara (ASN), pasal 48 (huruf g) memiliki tugas untuk melakukan pendataan terhadap pelanggaran disiplin yang dilakukan PNS dan hukuman disiplin yang telah diterapkan guna menyikapi pelanggaran. ${ }^{35}$

${ }^{34}$ Sudirman, S. (2018). Netralitas Aparatur Sipil Negara Pada Pelaksanaan Pemilihan Kepala Daerah Di Kota Parepare, Skripsi, Fakultas Hukum Universitas Hasanuddin Makassar, h. 3

${ }^{35}$ https:// setkab.go.id/96-diberhentikan-tidak-hormat-sebanyak-1-759-pns-dijatuhihukuman-disiplin-tahun-2017/ diakses tanggal 10 Nopember 2019 
BKN telah melakukan sinkronisasi data pelanggaran netralitas dengan instansi pemerintah daerah (Provinsi/Kota/Kabupaten) pada tanggal 4-10 Juli 2019. Ketentuan jenis pelanggaran dan sanksi disiplin untuk PNS yang terbukti melanggar netralitas diatur dalam Peraturan Pemerintah Nomor 53 Tahun 2010 tentang Disiplin PNS. Terdapat dua jenis pelanggaran dan hukuman yang dikenakan bagi ASN yang melanggar netralitas. Pertama, jenis pelanggaran netralitas berkategori sanksi hukuman disiplin sedang meliputi: ikut serta sebagai pelaksana kampanye; menjadi peserta kampanye; mengadakan kegiatan yang mengarah keberpihakan terhadap pasangan calon; memberi dukungan kepada calon anggota Dewan Perwakilan Daerah atau calon Kepala Daerah/Wakil Kepala Daerah; lalu, terlibat kampanye untuk mendukung calon Kepala Daerah/Wakil Kepala Daerah; mengadakan kegiatan yang mengarah kepada keberpihakan terhadap pasangan calon yang menjadi peserta pemilu sebelum, selama, dan sesudah masa kampanye meliputi pertemuan, ajakan, imbauan, seruan, atau pemberian barang kepada PNS dalam lingkungan unit kerjanya, anggota keluarga, dan masyarakat. Sementara sanksi yang diterapkan dapat berupa: penundaan kenaikan gaji berkala selama satu tahun; penundaan kenaikan pangkat selama satu tahun; dan penurunan pangkat setingkat lebih rendah selama satu tahun. ${ }^{36}$

Kedua, jenis pelanggaran netralitas yang berkategori hukuman disiplin berat meliputi: sebagai peserta kampanye dengan menggunakan fasilitas negara; membuat keputusan dan/atau tindakan yang menguntungkan atau merugikan salah satu pasangan calon selama masa kampanye; lalu, menggunakan fasilitas yang terkait dengan jabatan dalam kegiatan kampanye; dan menjadi anggota dan/atau pengurus partai

\footnotetext{
36https://www.tribunnews.com/nasional/2019/07/24/bkn-sebanyak-991-pnsterlibat-pelanggaran-netralitas diakses tanggal 10 Nopember 2019
} 
politik. Terhadap pelanggaran itu, sanksi yang diterapkan dapat berupa: Penurunan pangkat setingkat lebih rendah selama tiga tahun; pemindahan dalam rangka penurunan jabatan setingkat lebih rendah; pembebasan dari jabatan; hingga Pemberhentian dengan hormat tidak atas permintaan sendiri sebagai PNS. ${ }^{37}$

Mekanisme dan persyaratan untuk penjatuhan hukumah disiplin berdasarkan Peraturan Pemerintah Nomor 53 Tahun 2010 yaitu: (1). Surat panggilan untuk dilakukan pemeriksaan (cukup 2 kali); (2). Berita Acara Pemeriksaan (BAP) yang dilakukan oleh Atasan Langsung; (3). Laporan kesimpulan hasil pemeriksaan dan saran pertirnbangan hukuman disiplin yang hendak dijatuhkan; (4). Daftar Hadir/Absensi PNS selama tidak masuk/meninggalkan tugas (bagi kasus tidak masuk kerja tanpa keterangan); (5). SK Calon PNS, SK PNS, SK Pangkat Terakhir, Keterangan Gaji Berkala terakhir dan SK Jabatan Terakhir (bila menjabat); (6). Data pendukung lainnya yang diperlukan atas pelanggaran disiplin yang dilakukan oleh yang bersangkutan. Semua kelengkapan/persyaratand imaksudd iatas dalam rangkap dua dan apabila berupa fotocopy hendaknya di legalisir oleh pejabat yang berwenang. ${ }^{38}$

Prosedur penanganan Hukuman Disiplin Ringan antara lain: (a). PNS yang diduga melakukan pelanggaran disiplin, dipanggil oleh atasan langsungnya untuk dilakukan pemeriksaan; (b). Jika PNS tersebut datang dalam panggilan 1 maka akan diproses Penjatuhan Hukuman Disiplinnya; (c). Sedangkan jika tidak hadir dalam pemanggilan 1 akan dilakukan panggilan Kedua dan jika tidak hadir juga maka akan dijatuhi hukuman disiplin sesuai Alat bukti yang ada. ${ }^{39}$

$37 \mathrm{Ibid}$.

38 https://bkpsdm.tabanankab.go.id/hukuman-disiplin-pns/ diakses tanggal 10 Nopember 2019

${ }^{39} \mathrm{Ibid}$. 
Untuk prosedur penanganan Hukuman Disiplin Sedang dan Berat antara lain: (a). PNS yang melakukan pelanggaran Disiplin dilakukan pemeriksaan oleh Tim Pemeriksa yang terdiri dari unsur pengawasan, kepegawaian dan Atasan langsung; (b). LHP dilaporkan secara hierarki Kepada Pejabat yang berwenang menghukum; (c). Pembuatan dan Penerbitan SK Penjatuhan Hukuman Disiplin PNS oleh Pejabat yang berwenang menghukum; (d). Setelah SK Terbit kemudian selanjutnya dilakukan penyerahan SK Disiplin PNS terhadap yang bersangkutan/Keluarga/melalui media elektronik (Cap Pos). ${ }^{40}$ Untuk tata cara penegakan disiplin pegawai menurut Peraturan Kepala Badan Tenaga Nuklir Nasional Nomor 6 Tahun 2013 Tentang Pedoman Penegakan Disiplin Dan Penjatuhan Hukuman Disiplin Pegawai Badan Tenaga Nuklir Nasional Bab IV menyebutkan antara lain:

\section{A. Pemanggilan}

1. Atasan langsung atau Tim Pemeriksa wajib melakukan pemanggilan secara tertulis kepada Pegawai yang diduga melakukan pelanggaran disiplin.

2. Pemanggilan Pegawai harus memperhatikan waktu yang diperlukan untuk menyampaikan dan diterimanya surat panggilan sesuai dengan alamat terakhir.

3. Pemanggilan dilakukan oleh atasan langsung atau Tim Pemeriksa paling lambat 7 (tujuh) hari kerja sebelum tanggal pemeriksaan.

4. Apabila Pegawai yang bersangkutan pada tanggal pemeriksaan tidak hadir, maka dilakukan pemanggilan kedua paling lambat 7

40 Ibid. 
(tujuh) hari kerja sejak tanggal seharusnya yang bersangkutan diperiksa pada pemanggilan pertama.

5. Pejabat yang berwenang menghukum menjatuhkan hukuman disiplin berdasarkan alat bukti dan keterangan yang ada tanpa dilakukan pemeriksaan terhadap Pegawai yang tidak hadir setelah dilakukan 2 (dua) kali pemanggilan.

B. Pemeriksaan

1. Mekanisme Pemeriksaan

a. Atasan langsung atau Tim Pemeriksa wajib mempelajari terlebih dahulu bahan-bahan dugaan pelanggaran yang dilakukan Pegawai sebelum dilakukan pemeriksaan.

b. Pemeriksaan dilakukan secara tertutup, hanya diketahui dan dihadiri oleh Pemeriksa dan Pegawai yang diperiksa.

c. Pegawai yang diduga melakukan pelanggaran yang kewenangan penjatuhan hukuman disiplin menjadi wewenang Presiden, maka pemeriksaan dilakukan oleh Pejabat Pembina Kepegawaian.

d. Untuk mempercepat pemeriksaan, Pejabat Pembina Kepegawaian dapat memerintahkan pejabat di bawahnya dalam lingkungan kekuasaannya untuk melakukan pemeriksaan terhadap Pegawai yang diduga melakukan pelanggaran disiplin, dengan ketentuan bahwa pejabat yang diperintahkan untuk melakukan pemeriksaan itu tidak boleh berpangkat dan/atau memangku jabatan yang lebih rendah dari Pegawai yang diperiksa.

e. Pegawai yang diperiksa wajib menjawab semua pertanyaan yang diajukan dan jika tidak mau menjawab, maka yang bersangkutan dianggap mengakui pelanggaran yang dituduhkan kepadanya. 
f. Atasan langsung atau Tim Pemeriksa wajib membuat Berita Acara Pemeriksaan (BAP)

g. Apabila diperlukan, atasan langsung atau Tim Pemeriksa atau Pejabat yang berwenang menghukum dapat meminta keterangan dari orang lain untuk mendapat keterangan lebih lengkap dan menjamin obyektivitas dalam pemeriksaan.

h. Pegawai yang mempersulit pemeriksaan tidak menghambat penjatuhan hukuman disiplin berdasarkan alat bukti yang ada.

2. Kewenangan penjatuhan hukuman disiplin

a. Apabila menurut hasil pemeriksaan, kewenangan untuk menjatuhkan hukuman disiplin kepada Pegawai tersebut merupakan kewenangan:

1) atasan langsung yang bersangkutan, maka atasan langsung tersebut wajib menjatuhkan hukuman disiplin (dengan membuat dan menandatangani Keputusan hukuman disiplin);

2) pejabat yang lebih tinggi, maka atasan langsung tersebut wajib melaporkan secara hierarki disertai berita acara pemeriksaan, laporan kewenangan penjatuhan hukuman disiplin dengan menggunakan format disertai konsep Keputusan hukuman disiplin menggunakan kertas berlogo instansi dan sudah siap ditandatangani oleh pejabat yang berwenang menghukum).

b. Untuk pelanggaran disiplin yang ancaman hukumannya tingkat sedang atau berat, Kepala instansi selaku Pejabat Pembina Kepegawaian atau Kepala Unit Kerja dapat membentuk Tim Pemeriksa yang terdiri dari atasan langsung, unsur pengawasan (auditor), unsur kepegawaian atau pejabat lain yang ditunjuk. 
c. Jika atasan langsung Pegawai yang bersangkutan juga terlibat dalam pelanggaran yang dilakukan oleh Pegawai yang bersangkutan, maka yang menjadi anggota Tim Pemeriksa adalah atasan yang lebih tinggi secara berjenjang atau hierarki.

\section{PENUTUP}

\section{a. Kesimpulan}

Dari uraian pembahasan pada bab-bab sebelumnya, maka kesimpulan dari penulisan karya ilmiah ini adalah:

1. Belum adanya efektivitas hukuman disiplin berat menurut hukum kepegawaian yang sekarang berlaku bagi Pegawai Negeri Sipil (PNS) karena pada kenyataannya, pelanggaran hukum terus terjadi di kalangan Pegawai Negeri Sipil (PNS) kendati sudah diberikan hukuman disiplin berat sehingga harus ada penegakan hukum yang lebih tegas yang seharusnya diatur dalam hukum kepegawaian.

2. Proses hukuman disiplin berat bagi Pegawai Negeri Sipil (PNS) antara lain: (a). PNS yang melakukan pelanggaran disiplin dilakukan pemeriksaan oleh Tim Pemeriksa yang terdiri dari unsur pengawasan, kepegawaian dan Atasan langsung; (b). LHP dilaporkan secara hierarki Kepada Pejabat yang berwenang menghukum; (c). Pembuatan dan Penerbitan SK Penjatuhan Hukuman Disiplin PNS oleh Pejabat yang berwenang menghukum; (d). Setelah SK Terbit kemudian selanjutnya dilakukan penyerahan SK Disiplin PNS terhadap yang bersangkutan/Keluarga/melalui media elektronik (Cap Pos).

\section{Daftar Pustaka}

\section{Buku}

Arief, B.N. (2002). Kebijakan Hukum Pidana. Bandung: PT. Citra Aditya Bakti 
Djatmika, S dan Marsono. (1995). Hukum Kepegawaian di Indonesia. Jakarta: Djambatan

Fajar, M dan Achmad, Y. (2010). Dualisme Penelitian Hukum Normatif dan Empiris, Yogyakarta: Pustaka Pelajar

Hartini, S, Sudrajat, T, Kadarsih, S. (2008). Hukum Kepegawaian Di Indonesia. Jakarta: Sinar Grafika

Marzuki, P.M. (2008). Penelitian Hukum. Cet 2. Jakarta: Kencana

Muhammad, A. (2004). Hukum dan Penelitian Hukum. Cet. 1. Bandung: PT. Citra AdityaBakti

Patria, A. (2015). Intervensi Politik dan Netralitas Aparatur Sipil Negara dalam Pemilihan Umum Kepala Daerah Provinsi Lampung Tahun 2014. Bandar Lampung: Faklutas Ilmu Sosial dan Ilmu Politik Universitas Lampung

Soemitro, R.H. (1990). Metodologi Penelitian Hukum dan Jurimetri. Jakarta: Ghalia Indonesia

Soekanto, S. (2006). Pengantar Penelitian Hukum. Jakarta: Penerbit Universitas Indonesia

Soekanto, S. (2016). Faktor-Faktor Yang Mempengaruhi Penegakan Hukum. Jakarta: PT. Raja Grasindo Persada

Soekanto, S dan Mamudji, S. (1990). Penelitian Hukum Normatif Suatu Tinjauan Singkat. Cet. 3. Jakarta: Rajawali Pers.

. (2009). Penelitian Hukum Normatif Suatu Tinjauan Singkat, Cetakan ke - 11. Jakarta: PT Raja Grafindo Persada

Sudirman, S. (2018). Netralitas Aparatur Sipil Negara Pada Pelaksanaan Pemilihan Kepala Daerah Di Kota Parepare, Skripsi, Fakultas Hukum Universitas Hasanuddin Makassar

Sunarso, S. (2012). Victimologi Dalam Sistem Peradilan Pidana. Jakarta Timur: Sinar Grafika

Yamin, M. H. (2013). Netralitas Pegawai Negeri Sipil dalam Pemilihan Umum Kepala Daerah di Kabupaten Takalar. Makasar: Bagian Hukum Tata Negara Fakultas Hukum 


\section{Jurnal Ilmiah}

Muvariz, F.R. (2019). Analisis Aspek Keadilan Dari Pemberhentian Tidak Dengan Hormat Sebagai Pegawai Negeri Sipil Di Indonesia. Jurnal Legislasi Indonesia Vol 16 No.2 - Juni 2019 : 190-202

Nugraha, H.S. (2018). Politik Hukum Pengaturan Netralitas Aparatur Sipil Negara Dalam Pemilihan Kepala Daerah Tahun 2018. Jurnal Justisi Hukum. ISSN 2528-2638 Vol 3, No. 1, September 2018

Perdana, G. (2019). Menjaga Netralitas ASN dari Politisasi Birokrasi, Jurnal Negara Hukum: Vol. 10, No. 1, Juni 2019

Yusuf, A. (2015). Pemberian Sanksi Pelanggaran Disiplin Aparatur Sipil Negara Dilingkungan Pemerintah Daerah Kabupaten Sigi Guna Meningkatkan Pelayanan Publik, e-Jurnal Katalogis, Volume 3 Nomor 11, Nopember 2015

\section{Artikel Internet}

https:/ / www.eduspensa.id/hukum/ diakses tanggal 10 Nopember 2019

https:/ /lektur.id/arti-kepegawaian/ diakses tanggal 10 Nopember 2019

https:/ / www.liputan6.com/bisnis/read/3939766/bkn-temukan-990pelanggaran-netralitas-pns diakses tanggal 10 Nopember 2019

https:/ / www.cnbcindonesia.com/news/20190726075238-4-87722/pnsingat-dilarang-dukung-capres diakses tanggal 10 Nopember 2019

https:/ / www.kasn.go.id/details/item/235-pilkada-2018-kasn-terima-200laporan-pns-terlibat-kampanye diakses tanggal 10 Nopember 2019 https:/ / baliexpress.jawapos.com/read/2018/05/28/77091/soal-masakampanye-pilkada-2018-dan-masalah-netralitas-asnpns diakses tanggal 10 Nopember 2019

https:/ / www.suarantb.com/politik/2018/12/264987/Terlibat.Kampanye,D elapan.ASN.di.Bima.Langgar.Netralitas/ diakses tanggal 10 Nopember 2019

https:/ /regional.kompas.com/read/2019/03/22/10045051/5-fakta-kasusfoto-6-asn-acungkan-2-jari-di-sekolah-bawa-stiker-prabowo?page=all diakses tanggal 10 Nopember 2019 
https:/ / kumparan.com/birokrat-menulis/menumbuhkan-kesadaranpolitik-kritis-asn-zaman-now diakses tanggal 10 Nopember 2019

https:/ / www.hukumonline.com/berita/baca/lt5c9336c8ba66d/pemilu2019-dan-netralitas-asn-oleh--hani-adhani/ diakses tanggal 10 Nopember 2019

https:/ / tirto.id/ bawaslu-izinkan-asn-ikut-kampanye-pilkada-dan-pemilucJMj diakses tanggal 10 Nopember 2019

https:/ / www.liputan6.com/citizen6/read/3871421/pengertian-hukumadalah-dan-jenis-jenisnya-yang-harus-dipelajari-biar-tak-salah-kaprah diakses tanggal 10 Nopember 2019

https:/ / nasional.sindonews.com/read/1281390/15/penegakan-disiplinpns-dinilai-belum-maksimal-ini-penyebabnya-1518411884 diakses tanggal 10 Nopember 2019

https:/ / setkab.go.id/96-diberhentikan-tidak-hormat-sebanyak-1-759-pnsdijatuhi-hukuman-disiplin-tahun-2017/ diakses tanggal 10 Nopember 2019

https:/ / www.tribunnews.com/nasional/2019/07/24/bkn-sebanyak-991pns-terlibat-pelanggaran-netralitas diakses tanggal 10 Nopember 2019

https://bkpsdm.tabanankab.go.id/hukuman-disiplin-pns/ diakses tanggal 10 Nopember 2019 